\title{
Families, Nations and Generations in Women's International Migration
}

\author{
Parry Scott
}

\section{Resumo}

Quatro experiencias de migração de mulheres de recife para Europa estão examinadas com ênfase no assunto de sociabilidade entre gerações, famílias e relações de gênero. Emprega-se o método genealógico como instrument para compreender a lógica de relacionalidade e de mobilidade. As genealogias de mulheres relativamente idosas revela a importância das relações de parentesco e do fato do Recife ser uma cidade de destinos migratórios plurais. As hierarquias de geração e de gènero influenciam as decisões sobre cuidados, limpeza, casamentos e mobilidade. A solidariedade dos grupos femininmos é contra-balançada por inciativas masculinas e por privilégios masculinos em eventos de migração. Redefinições e reafirmações se narram em relação à autonomia e à subordinação das migrantes. As referèncias familiars são vistas como mecanismos disponíveis para enfrentar favoravelmente as barreiras legais nacionais a mobilidade. Os relatos das informants mais idosas relegam as suas opiniões sobre diferenças nacionais e culturais a um segundo plano ao falar sobre as obrigações familiares e de parentesco. As migrantes alcançam alguma autonomia e confrontam estruturas sociopolíticas, mesmo diante da subordinação dupla de gênero e de inserção em redes de parentesco hierárquicas.

Palavras-chave: Migração Internacional; Mulheres; Gerações; Relações de Gênero; Família, Redes, Genealogias

\section{Abstract}

Four experiences of women's migration from Recife to Europe are examined emphasizing sociability between generations, families and gender relations. The genealogical method is used as a tool to understand the logic of relatedness and mobility. Elder women's genealogies reveal the importance of kin relations and of Recife being a city of plural migrant destinations. Generational and gender hierarchies influence decisions about 
caretaking, cleaning, marriages and mobility. Women's group solidarity is counterbalanced by male initiatives and patrilateral privileges in migration events. Redefinitions and reaffirmations of generational hierarchies are narrated in relation to migrant autonomy and subordination. Family references are seen as available mechanisms to circumvent national legal barriers to mobility. Informants' accounts of migrant experience relegate opinions about national and cultural differences as secondary to discourse about family and kin obligations. Migrants establish some autonomy and confront sociopolitical structures, even when facing double gender subordination and insertion in hierarchical kin networks.

Keywords: International Migration; Women; Generations; Gender Relations; Family; Networks; Genealogies 


\title{
Families, Nations and Generations in Women's International Migration
}

\author{
Parry Scott ${ }^{7}$
}

The genealogical method for collecting kin networks and discussing relatedness and material and symbolic flows between international migrants and their families is a valuable tool for understanding human mobility as part of intertwined sociability and life strategies which mobilize families and generations. This study emphasizes how family and generational relations are materially and symbolically articulated by women enmeshed in these international relational flows and counterflows. The emphasis is on how this particular kind of international ${ }^{2}$ sociability both strengthens and weakens solidarity and conflicts between generations and family members, identifying, when possible, some effects of these networks on the understanding and operation of images of national differences and of mobility legislation. The principal data base was produced in Recife, Pernambuco, where genealogies of three grandmothers and one mother were constructed over a period of several months, engaging in more than five formal sessions of genealogy construction and numerous other long and short conversations about specific subjects related principally, but not only, to relations with migrants in

\footnotetext{
$1 \quad$ Full Professor of Anthropology, Federal University of Pernambuco, (scott@hotlink.com.br). Support from CNPQ project “A Família no Meio do Mundo" (302080/2007-4, 306033/2010-0 ). The field research team of undergraduate students included Mariama Vicente, Leonardo Nóbrega and Rafael Acioly who co-authored two presentations: one at the Reunião Equatorial de Antropologia - ABA - Norte/Nordeste, GT 14 migrações internacionais, UFRN, 2009 (As rearticulações de sociabilidade decorrentes de migrações internacionais), and the other at the XIV CISO in Recife-UFRPE-UFPE-FUNDAJ, 2009.(Identidades nacionais forjadas em redes de parentesco: a migração internacional sob a ótica de morais familiares).

2 Just as many other authors, I prefer the term "international" to "diasporic" because the first term makes reference to political, legal and ideological boundaries without predetermining an idea of a fixed homeland or a suffered separation from it which the second term suggests. The American Heritage dictionary first associates diaspora with the historical dispersion or exile of the Jewish population and then generalizes for "A dispersion of a people from their original homeland....[and] The community formed by such a people.” (http://www.thefreedictionary.com/Diaspora) accessed October 20, 2011.
} 
their network. Two criteria were used to choose the women: friendship or relative closeness to the researchers, and the existence of at least one international migrant in their genealogy. Using this data, intra and interfamily and intra and intergenerational relations are detailed in their contexts and a dialogue established between the findings of this fieldwork and part of the social science literature on family and generation in international migration. International mobility has become a contemporary sounding board for the observation of the effects of mobility on family, kinship and friendship networks and on how public policies (especially, but not only, in the sphere of immigrations) contribute to the configuration of these social relations. The decision to transnationalize mobility introduces factors which strongly differentiate this experience from other non-transnationalized migration which commonly occurs in the formation of such networks. Historically, transnationalized migration can be identified in relation to the experience of older generations and in specific contexts, but contemporary transnational mobility patterns affect more directly middle and younger generations and are particularly far-reaching, involving a hitherto unseen opportunity for international communication and travel.

In the next section a brief consideration of how genealogies reflect overarching migration patterns serves as a basis for a discussion of the research methodology and of historic changes in national and international mobility. This is followed by a presentation of one experience taken from each of the four genealogies emphasizing gender, family and generational factors in the forming of group solidarities in different mobility contexts. A basic premise of this study is that families, relatives and friends manage to produce continuities in their sociability networks at a distance exactly because mobility itself makes up part of the logic of their group relations with socioeconomic and political structures which are sustained by the very mobility which they provoke.

\section{Migration in Genealogies and Relatedness Networks}

Anthropologists have long recognized that the most complete genealogies are done with older informants. In 1987 Myriam Lins de Barros used field research on upper middle class grandmothers and grandfathers in Rio de Janeiro and showed that their privileged memories of both previous and succeeding generations make them reference points for the construction of five-tiered generational networks on the basis of sentiments of authority and of affection. 
The four genealogies in Recife were done with women between 45 e 75 years of age. Since they are of quite different ages, the range of their genealogical memory is quite varied; nevertheless, in all cases there is a wealth of information about people who are closely related to the informant. The decision to emphasize family and kin relations shifts the focus in migration studies away from national, state and local boundaries which are used in the formal statistical construction of geopolitically measurable flows. It permits the visualization of a series of intensely-related persons in fragments of individualized webs of relatedness. It emphasizes those who are "considered" kin, but when it is accompanied by accounts of migration events, the webs enlarge to include other "related" people, much as Carsten (2004) argues about the growth of feelings of relatedness which are not based simply on biological and marriage ties.

Clifford (2000) insists that human mobility must be taken into account to avoid a stagnant, localized treatment of "culture" in much the same way as Ulf Hannerz $(1999,1997)$ has argued concerning the terms "local" and global" applied to the plurality of flows between people in different places:

"the relational point of view becomes more fundamental than the presuppositions about space and locality. Relations can extend over larger or smaller spaces, but this can be dealt with using a flexible conceptual framework, instead of using a mystifying dichotomy $(1997,151) . " 3$.

More recently, Portes and Dewind (2007) have put together an impressive collection of articles on different ways that national immigration policies are applied to favor the establishment of physically distant, closely-related migrants. International mobility strategies frequently include the preservation and reinforcement of networks of "close" relatives and a search for dual citizenship as a way to circumvent the immobilization which illegal or clandestine status confers on many, straining physical proximity-based bonds. For these migrants, the construction and reinforcement of social networks are very powerful stimulants to action, whether they themselves are mobile or not. Reified cultural differences (food, music, clothes, folklore, festive dates,

3 Texto original: “a visão relacional se torna mais fundamental do que os pressupostos sobre espaço e localidade. É certo que as relações podem se estender através de um espaço maior ou menor, mas podese lidar com elas através de um arcabouço conceitual flexível, em vez de terminar com uma dicotomia mistificadora" 
literature, etc.) become salient and ever-present features which enable the organization of both strategies and thought about network construction. These cultural features themselves, even if important, do not operate independently of their constituent networks of social relations.

The women who were reference points for the Recife genealogies gave detailed accounts of the meanings they conferred on events which involved closely-related migrants in their network. In general, for all migrants, independent of perceived closeness or distance, these accounts were very rich in details about strategic action and about normative declarations concerning expected obligations and characteristics. Even when these declarations address legal rights and cultural and national differences, their normative content deals more with kin relation norms than with culture and nationality characteristics themselves.

In terms of generations, and in consonance with the historical flows of international migration, the accounts heard were from elder generations concerning international events which occurred with younger generations. These accounts, consequently, are intergenerational and are of women whose own life experience led them to migrate within Brazil and establish residence in Recife, but who have virtually no more expectations of leaving the Metropolitan Area. They are viewing relatively new patterns of international migration by younger generations of their networks, remembering how previous national and local migrations affected their own lives, and commenting on how international migration affects their kin networks without imagining themselves as potential migrants. They are enmeshed in the networks, but they themselves are not mobile (except for occasional visits). Their comments reconfirm the importance of authority and affection over a very wide range of generations.

The genealogical accounts permitted the identification of variable "houses of reference" for the construction of the kin network. In all four cases the first house of reference, when the informants speak of the older generations in their network, is the house of their parents, which is associated with their experiences as children and youth. The second "house of reference" is their own home, referred to when dealing with younger generations, and this becomes the focus of conversations about international migration. It is interesting to note that in conversations about their own generation, even with some shared group preferences, there appears a greater variability of houses of reference, depending principally on the number and order of siblings. 
With reference to more rural Northern Portugal, Pina Cabral (2003) recomposed kin networks and migration using four houses of reference showing how important these houses are for relative cohesiveness between relatives who have become physically separated over time. The fact that Recife is more urban and the migration processes described involve greater distance and more intense national and legal barriers to mobility does not obliterate the idea of a "house of reference," but it does make these houses of reference more flexible and variable, creating a plurality of opportunities for the construction of solidarity networks between younger migrants and nonmigrants. Even more so when it is taken into account that there is no specific destination which has come to be associated with Recife, different from migration flows seen in Goiânia, Governador Valadares, and Criciúma, where the repetitions of destinations denounce a shared multi-generational strategy resorting to practices which take advantage of networks that virtually always extrapolate kin relations. In these other cases the extra-kin and family factors in the establishment of economic enterprises become fundamental to the characterization of economies in the Brazilian reference point and create widely shared symbolic references to mobility flows. Over the last few decades international migration of Brazilians has received much attention, and several recent collections of studies (Castro 2003; Martes and Fleischer 2003; Fonseca 2007; Fundação Alexandre Gusmão 2008a, 2008b; Feldman-Bianco 2010; Ferreira et. al. 2010) have shown that ethnographic studies of specific cases, with their inherent limits to generalization, contribute greatly to the understanding both of the complexity of the phenomenon and to the interpretation of data produced by other means. Undeniably, these studies have established a tradition of new contributions to a greater understanding of families, generation and networks produced in the context of human mobility.

As an example of how much information can be obtained in a single genealogy, a 63 year old informant of the familia no meio do mundo research referred to almost 300 relatives, 272 of whom she identified by their names. She gave many details about her mother, father, her seven brothers and sisters, her son and daughter, and some selected relatives among the sixteen consanguineal uncles and aunts, forty-six first cousins, twenty nieces and nephews, as well as her grandparents, grand-nephews and nieces and husbands and wives of a good part of these relatives. Her parental home of reference is in rural Paraiba, with núcleii of relatives who form complementary houses 
of reference in Campina Grande, Rio de Janeiro and Recife. The number of migration events is enormous, varying as a function of the limits which the researcher imposes on what he understands as migration (residential, geopolitical, etc.). Among all these relations there are many accounts of travel and affinity with foreign countries: a missionary aunt married an Englishman in Africa and now lives in England and "might have some children"; an adoptive niece who was "re-adopted" in Switzerland; a nephew who left his wife and children in Rio and went to live and work in the United States and only returned when he began to face a combination of the closing of his import-export firm and serious health problems; a niece who took her two children to Australia to accompany her husband's transfer as an executive employee of a multinational enterprise; and another niece who met an Italian during a stay on an international trip she made to help her cousin with child care, got married, and moved to where she now lives near the Swiss-Italian boundary. And these accounts exclude, somewhat artificially, periods of several years spent abroad in study and exchange programs with the express intention to return to Brazil, which characterize both the informant's own experience with her husband, and the multiple experiences of her children, and of several other young relatives.

Dealing with four genealogies, then, means that data is available on thousands of kin relationships and migration events (see Barnard and Good 1984), but, in the case of this study, one case will be selected from each genealogy in order to generate a deeper understand of families and generations in different contexts of international migration.

\section{Four Experiences}

Four experiences were intentionally chosen on the basis of the quality of the data collected about norms, strategies and practices of social network construction related to specific events. After a brief outline of the principal characteristics of each event, more detailed accounts are elaborated in the following discussion of gender, family and generation, presenting more details as the narratives about practices unfold and shed light on the dynamics of the articulation of kin and social network rights and obligations with international legal and political contexts: 
a) Lea is the sister of the youngest informant ${ }^{4}$. When she was around twenty-five years old she moved to Portugal. Her Angolan husband fled the civil war in his country and spent a number of years in Rio and then in Recife. Lea had three young daughters with him, but when he became unemployed he decided to return to his parents' home in Portugal. Lea spent some time with her children in her sister's house in Recife, and then travelled to Portugal six months later with her three daughters and resided with her mother-in-law and father-in-law for a period before establishing an independent home with her husband and children.

b) Ruth is the niece of another informant. She went to live in Germany on the invitation of her older sister who had travelled announcing the intention to learn the German language, met and married a German, separated from him, and remarried with another German. Ruth was somewhere between twenty-five and thirty years old when her sister said that she should travel, take advantage of a chance to live with her and learn the language. She also met a German, married and had a son and took up residence.

c) Samantha also is a niece of another informant. When she was about to complete her twenty-fifth birthday she went to Switzerland, near the Italian border, to marry an Italian student that she had met when she went to Australia to help her cousin care for her two young children. During her outings with the children she met the Italian student, who was on vacation and they started a relationship that resulted in plans to reunite in his homeland, near his parents' home in a Northern Italian town, after she returned from Australia. She spent a short stay back with her relatives in Brazil and went off to live in Switzerland.

d) Maria is the daughter-in-law and the mother of three grandchildren of another informant. Her three children continue living in the informant's home in Pernambuco, even after she became an ex-mother-in-law. Maria separated from her husband and spent around three years under- and unemployed before her move to Spain. After their separation, her husband returned to his maternal home (the informant's home), and every time that Maria got a job in Pernambuco, she took her children back to her motherin-law's house to be taken care of. When her ex-husband remarried, he left his mother's home, but she still took on the responsibility for care of her

4 The names are fictitious. 
grandchildren when Maria found work. After about three years of this postseparation child circulation, when Maria was about thirty years old, she accepted an invitation from her older brother to come, illegally, to Spain to work in domestic service, housecleaning and boat care. Judging the difficulties of illegal travel with children, she once more left her children behind and began a new life, working and remarrying with a Spaniard, and developing unsuccessful strategies for reuniting with her three children.

In all of the chosen cases the migrations are of women in their mid or late twenties. Not including the very few cases of international migration among former generations, and excluding dependent children, the four genealogies identified ten international migrations, eight of which were feminine, always with a predominance of migrants of similar ages. The feminilization of international migration has been recognized by many authors as a phenomenon which predominates in Latin American migrant flows (Anthias 2000; Arango, 2007; Scott, 2007; Piscitelli, 2008, Cachón 2007). This movement is associated to many different questions, among them: the success of feminist movements which broke down barriers to mobility and stimulated the search of autonomy and involvement in public spheres; the increasing opportunities in the labor market for women in general; and, putting the ideas together, the specific configuration of reduced fecundity rates in developed countries which diminished the supply of young female caretakers and domestic workers and even wives to take the place of native working women in these countries (Scott 2007; Roca Girona 2007). Previously, long distance mobility was seen as more restricted to men because of their supposedly greater will to face risk and danger and the consequent gains to male prestige for having had the courage to venture away from home, The taboos to female participation in such mobility, more prone to be under active vigilance of their parents and communities, have diminished, and women have ventured into long distance migration. At the same time, evidence of different stigmatizing meanings may be attributed to such movement. An example of this is in relation to the market of sex which, as a flow in which women are the principal migrants, receives a disproportional amount of attention when compared to its reduced statistical prevalences. Certainly the 
seriousness and specificity of this migration flow show how strongly preconceived notions of gender relations relegate female participation to sexual services when the great majority of female migrants are working in other (also very traditionally feminine!) services.

The variety of destinations certainly has to do with the fact that a criterion for choosing informants was they had "someone who has had international migrant experience in their network," without, however, specifying the destinations. But the same variety has to do with the local indefinition of a symbolically favored international destination for habitants of Recife. Besides Portugal, Spain, Switzerland and Germany, there were migrations to Italy, England, Australia, El Salvador and the United States. Brazilians, as do other migrants, frequently reside in relatively segregated immigrant communities abroad, and this is one of the ways in which important adaptations and articulations with the new context are done. All immigrant communities present internal fragmentation, and Brazil is no exception, to the point that many observers believe that this internal divisiveness leads to a relative invisibilty of Brazilian communities in many countries. In addition many Brazilians abroad are mixed in with other population, and this diminished residential concentration increases invisibility. Cohesive immigrant collective actions tend to occur exactly when there is more residential segregation. But the emphasis here is not on the visibility or invisibility of immigrant communities in their new geopolitical context, but rather on how their family and generation sociability networks are rearticulated in these conditions. Young women migrants build ambiguous strategies in search of autonomy, working in traditionally feminine spheres and resorting to marriage alliances whose real consequences on autonomy of both practices are, at the least, dubious. Reworking of family and generational relations occurs in a context of still not-so-free international and local circulation (see Scott 2004[2011], 2011).

\section{Families and strategically articulated female networks}

In each of the four experiences, strategies are articulated by groups of closely-related women to continue to include the migratory event in relational networks loosely or tightly associated to kin networks of the informant. This is very clear in the descriptions of informants who symbolically value positively

can be seen in Cadernos PAGU (31) 2008 e (15) 2005. 
practices which reinforce the migrant's connections to the network. There is a recognition of individuality and search for autonomy by migrants and their search for citizenship and other rights, but the gains are judged as more positive or more negative in relation to the astuteness of their use of an understanding of the formal migration contexts, and, above all, of their repercussions for network participants and the diverse individual and group projects which operate in their loosely planned network cooperation.

In a now classic Brazilian study of rural-urban migration between the 1930's and the 1960's Eunice Durham (1973) observed that the principal operational element at work in the network of social relations of migrant group projects is kinship. Kin offer emotional and financial support for first-time migrants, and are the principal participants in the preparation of travel of following migrants. This network is also the reference to judge the advisability of continuing migrant flows, or promoting returns. Obviously this means that the kin network has a variable reading of political and legal contexts, but it also means that these contexts are complementary to the importance of mobility for understanding of the importance of retraction or expansion for network solidarity and individual success. What calls attention is that it is women who are activated to overtly keep families ties in operation, even when there is a separation based on spatial distance. "It is the mothers that "don't work for others" who begin kin and neighbor relations in which their husbands and unmarried children participate by way of the women" (Durham, 1973: 208) $)^{6}$. That makes middle-aged and elderly women privileged informants about kin networks.

Women's dedication to the private sphere and to care relations affects both their more intense involvement in kin network construction and the characteristics of their job placement when they seek their autonomy and independence through work. Women, especially those from elder generations, take care of their close relatives who cannot travel immediately, of children who cannot be exposed to illegal or unsafe migration, of property and belongings that could not be taken or sold, and, very often, in finding or furnishing the resources necessary to pay the costs of the migration. The synthesis of data on remittances from migrants abroad in Schweizer (2008),

6 (original) "São as mães que 'não trabalham fora', que iniciam e mantêm as relações de parentesco e vizinhança, nas quais maridos e filhos solteiros participam, por assim dizer, por intermédio das mulheres" 
besides emphasizing their economic importance for the nation, for specific locales and for family groups, show that women are privileged recipients, and that they are often from the same generation as the migrant, making up a web of caretakers that further investigation would probably show include elder generations (mothers) who are not direct recipients (in part because of their more limited understanding of some international monetary transactions), but who are important cogs in the family and network administration of resources related not only to their symbolic centrality in family construction, but also to their direct activities in caretaking.

In the four migrant experiences presented, there are always key women articulators of group relations that facilitate individual mobility. Of particular importance are the residential sharing and care cooperation offered by Lea's sister in Recife, and then by her mother-in-law in Portugal; before going to Switzerland, Samantha's aunt and uncle offered their home upon her return trip from Australia, where her cousin had offered housing and income for her stay that resulted in her marriage and more permanent mobility plans; Maria's ex-mother-in-law cared for her three children when the opportunity to travel to Spain appeared; and it was Ruth's sister who offered lodging when she travelled to study in Germany.

Longer accounts of these migrations reveal more details and permit denser interpretations. First, a closer look at the practices which surround the opportunities for women to migrate show a more complex operating practice of gender and generation hierarchies in kin networks. Second, the quality of work and its relation to caretaking and symbolically feminine activities is also examined from the point of view of gender relations in the context of international migration.

Lea and Maria, even if they depended heavily on women in their networks, both went to the Iberian Peninsula under male incentives. Lea decided to accompany her husband in search of better work, and better conditions for his family, which he associated to the reception of support from his own parents, who had fled Angola and gone to Lisbon and were willing to offer residence and support for their son and his family. When her husband went alone, six months before Lea and the children followed, he said he would find a job and organize the best living conditions possible, and, effectively, he intensified his ties with his own kin network. In the other migration to the Iberian Peninsula, Maria accepted an invitation made by her brother. He 
had already been residing in Spain for several years when his contact with his sister sensitized him to her difficulty in finding a good job and led him to suggest she travel to stay with him. Later, she found a husband. Ruth accepted her sister's invitation, but after several months she had found a German husband and went to live near him and his family. Samantha, travelled from place to place by invitation from her aunt to study and live in Recife, by her uncle to Brasilia for similar reasons, and her cousin to Joinville and then to Australia to help care for her cousin's children, but she finally makes up part of her husband's kin network in Switzerland and Northern Italy, where she established residence after marrying.

Gláucia Assis (2003), studying migrations between Criciúma and the United States reports that women usually travel accompanied by someone from their family, and men travel alone or in the company of friends and colleagues. Although Lea was, in fact the only woman who, in fact, travelled with her family (her three daughters), all of the other migrants travelled with clear plans to stay with a family member. There are variable and multiple overt reasons for the travel: Lea to preserve her marriage; Maria to find income to provide for herself and her children; Ruth to study a new language and make friends abroad; and Samantha to help her cousin and make friends in Australia. As has been pointed out in national and international migration studies, the decision about where to go is strongly influenced by family networks in the sense that having someone closely related to receive the migrant makes for a less turbulent adaptation to the new place. Those who went first were more venturesome and got to know enough people and places to make the arrival of someone else easier (Durham, 1973; Fusco, 2001; Assis, 2003).

Once the decision to migrate has been made and the destination defined, the question becomes how to organize the travel and arrival. Women are frequently mobilized at this stage of the move. Case by case, more details become clear:

Financial need weighed on the decision of Lea and her husband to think about finding a better chance in Portugal with the help of his family. Her husband resided with his parents while he was looking for a job and tried to organize a place for his wife and children, which he was unable to do. Lea and her daughter stayed with her sister (the genealogy informant) over the six months between her husband's travel and their's. In Portugal Lea spent a full year in her parents-in-law's house, a period which her sister said was judged 
by Lea as a time when her mother-in-law endeavoured to teach her grandchildren how to behave themselves in the new country, learning Portuguese customs. Solidarity between women is very evident in this international network which changes from the matrilateral to the patrilateral side in function of migration. This solidarity did not mean a lack of conflict, because Lea was in open disagreement with the rigorous rules and punishment that the Angolan-Portuguese grandmother imposed on her daughters, something she could not contest very openly since she was living "as a favor". This feeling was only undone when she and her husband found, a year later, their own apartment and went to live on their own with their children, steeped in their recently acquired Portuguese manners. This relative independence remained up to her husband's death, a few years later, which is when his parents moved closer to their grandchildren's (and, of course Lea's) home to be able to help out even more.

Although Maria's brother was her "passport" to Spain, and his home served as base for her formally illegal income generation in domestic and cleaning services, it was her ex mother-in-law, who stayed behind in Brazil, who was the essential actor in her network, caring for her children with what was described (by his own mother!) as the sporadic and insufficient help from the children's remarried father. These two women, of different generations, divided the responsibility of bringing up Maria's children. They were in constant open and clear internet-aided communication via Skype. Difference of opinion about how to proceed arose, but it was very clear that the grandmother's availability as a caretaker included an overt intention to preserve links of affection between mother and children. Maria's motherin-law lamented that she had to be both grandmother and mother to the children, alleging that this forced her to take disciplinary measures that she wouldn't have to take if she were only the "grandmother".

This intergenerational transfer of childcare is frequently provoked by migration. Observers of women's migration from the Caribbean to New York and other United States destinations coined a term of generalized use in the 1970 and 1980s: the grandmother syndrome. It refers to the importance of migrant women's mothers (and mothers-in-law, one might add!) in taking care of children left behind by women who sought income and success for themselves abroad, and, indirectly, for their family left behind. The grandmother syndrome reinforces a unity between older and younger generations, 
overbalancing these age groups in the fragile demographic structures of the Caribbean islands (or other points of origin of migration), and leading working adult women to offer their work in a better-paying market, distant from their children. Disagreements about childcare, affection and rights over the children were frequently pointed out. In the beginning of the twenty-first century there has been a shift in terms which reveals a shift in emphases. Present-day discussion revolves around "migrant mothering and intimacy" (Shared transnational mothering in De Tona's terms [2011], mothering across boundaries in Pojmann's terms[2011])7, which reveals how modern communication and transportation facilities, without removing the generational differences, have put mothers more consistently in touch their children abroad, even when they are cared for by the grandparents. In these situations of mobility, there is an underlying generational dispute which classical RadcliffeBrown kinship theory interpretations, based on in-place local societies, understand as contributing to the functionally pacifying "uniting of alternate generations". Kinship theories that are not base on functional harmony point to cooperation and conflict in dealing with intimacy and domestic life without presupposing unity.

In the cases of Lea and Maria, mothers-in-law (or, in other terms, paternal grandmothers) gain authority and affection, negotiated at the cost of the mothers themselves. The criss-crossing of symbolic families reconfigures kin relations. Even though physically present, Lea loses her power to educate her own children as she sees fit because her mother-in-law provides housing and also is more experienced in the "Portuguese culture" in which the children will be brought up. She only regains some of such power with her residential independence, which becomes more precarious with the death of her husband. In the other case, Maria established an intermittent sharing of childcare and residence with her mother-in-law while looking for decent employment in Brazil, and this eased her decision to leave her children behind when the opportunity to go to Spain arose. A relational break that could have occurred with her separation, which theoretically could have resulted in fewer contacts with her in-laws, did not occur because of mutual interests of the two women over the children. Since Maria wished to reaffirm her role

7 Marcos Araújo Silva of the Anthropology Program at the Federal University of Pernambuco is developing a doctoral thesis in which he examines this phenomenon for migrants in Italy and Spain in one of the chapters. 
as mother, and her mother-in-law wished to be an active grandmother, after Maria's move to Spain she was retained in the kin network as the distant, yet ever-present, mother of resident grandchildren. Her ever-presence was virtual, and her unending instructions about proper behavior and professions of the continuing will to be together were done face to face, on-screen, as a mother abroad. She experienced frustrated attempts to integrate her children into Spanish culture, and was left with the impression of loss of control over her children.

In these two examples it is interesting to note that the loss of a male link in the kin relations (the death of Lea's husband and the separation from Maria's first husband) was more than compensated by the efforts of the mothers-in-law to keep their grandchildren within their spheres of activities. The force of female intergenerational links preserves family ties over long distances and over different cultures associated with national symbolism.

Samantha, who is seen by her kin as a person who demands special attention and care, is strongly protected by her uncles and aunts who operate as a network of siblings, united around an idea of giving as good support as possible for Samantha to become more mature. Her aunt in Recife took her in and promoted her studying when it became difficult for her own parents in the countryside to take care of her, and when the results of her studying began to wane, her uncle in Brasilia offered the same thing in hope that the change of cities would be a stimulant for study, and there she reached university level study. But even more important was the friendship she made with her uncle's daughter (her cousin) who had very young children, conditions that made Samantha's presence a pleasure for all, and she was invited to spend some time in Joinville, where her cousin's husband had found executive work. His transfer to Australia by the multinational corporation made it easy for them to propose that Samantha spend more time with them, helping with the kids, easing their mother's (her cousin's) setting up independent work. The idea of getting to know "the outback" had an enticing adventuresome aura to add to her informal childcare duties, so she continued to reside with her cousin's family in another hemisphere. She met another student from Italy who was on an adventuresome vacation, and they rapidly decided that they would go back to Switzerland, marry in both countries (Brazil and Switzerland) and live together.

In brief, in these women's migratory trajectories, even when they 
depended on men to begin or to offer support, what was effectively put into action was a predominantly feminine network in which marriages, jobs and, even moreso, caretaking, were essential elements. These elements are key to the understanding of women's international migration.

\section{Autonomy and family solidarity between generations}

A good deal of recent research on life cycles, life courses and life trajectories among the young (Dalsgaard et. al. 2008, Franch 2008, Muller 2008, Tavares 2009), review present literature on youth and take a stance contrary to linear treatments which overvalue sequences and transitions that refer to ideal models that have guided thought on youth over years. The opposition is more to the idea of linearity than to the idea of transition. Much to the contrary, hierarchically organized symbols of human development, even when they are inverted, are highly valued. An example of this is when adults are looked upon positively because they are "jovial, and young at heart". In this case, the adult generation continues to value its age bracket, at the same time that another series of values associated to the young accrues, emphasizing activeness, consumption and aesthetic appeal. It also opens up a field of intergenerational dialogue that permits a subjective search to flee from a negative symbolism of aging, using eufemisms that rejuvenate or ignore features that suggest losses and frailty for elder generations (as Debert has shown eloquently some time ago - 1999). Therborn (2008) shows that the decline of idealized family models and the rise of more flexible moral and legal accounts of living the family sphere are global phenomena which question fixed life courses and trajectories. Whether dealing with the United Nations 18 to 24 year old limits to the category of youth or extending the idea over a longer number of years (that would fit best in the cases discussed here), these questions become very relevant for the understanding of generations, autonomy and family solidarity.

Scott and Franch's study (2005) on the acquisition of skills and knowledge by youth identify five intersections which influence housing patterns as part of the creation of sociability networks in which spatially perceived limits define pedaços (Magnani, 1998) socially, as areas in which mutually well known people circulate and are favored: a) family and residence; b) gender; c) study and work; d) diversion and security; and e) patrimony, kinship and individuation. These interaction spheres provide a convenient clue for meanings 
attributed to decisions made about housing, or, more generally, about where to live as part of intergenerational communication.

The migrants described here had all gone through numerous residential redistributions before deciding on an international destination. This permitted the construction of numerous "houses of reference". Two were married previous to their travel, and two associated their travel to marriages. Even with three children Lea and her husband faced enormous difficulties in establishing their own "house of reference", becoming enmeshed in grandmothers' networks and battling to be on their own. Maria, with the same number of children and a turbulent phase of marital separations and attempts to return saw her influence over her own adolescent and pre-adolescent children wane as her mother-in-law (their grandmother) became the daily disciplinarian and focus of affection of the children, who demonstrated little interest in going to Spain. An attempt to convince her youngest daughter that she could be happy living with her in Spain resulted in a tense several month visit in which Spanish customs, Spanish food and a Spanish stepfather all figured in the girl's decision that she would prefer to stay with her sisters and her grandmother in Brazil, where she knew how things were.

Ruth and Samantha are the two migrants who had not spent time trying to establish post-marital residence. Yet marriages by close kin were important factors in their decisions. Ruth, relatively young, was invited by her sister who had gone through a marriage, a separation and a remarriage in Germany. Somewhat skeptical that "learning a language" was only a superficial excuse for the underlying reasons of finding a job or a husband, or both, her aunt narrated the "unexpected" marriage event as if it were the culmination of the real reason for travelling. Ruth's house of reference in Brazil had lost its power of attraction because both her parents had died. Leaving one sister's house in Recife to live in another sister's house in Germany, then, was not a particularly radical change in the search for a redefintion of a house of reference. Her sister that stayed behind said that she didn't understand how her sister could live with the arrogance, bad manners, intolerance and threats of violence of her German husband, in a declaration that clearly showed, through a comment on different cultures, that she had no intention of following her sisters' leads.

Samantha's experience in going to Switzerland was done as part of a long-reaching tight network of siblings and their offspring - aunt, uncle 
and cousin, who all looked after what they felt was best for her. She was a young representative of the elder generation's shared trajectory decades earlier, leaving a rural grandparental house of reference from which all had started but which continued offering few opportunities for the young in a mobile world. Since Samantha plodded along with difficulty, her reaching higher education in Brasilia was celebrated by all as a victory. Even more so, when the very unexpected marriage proposal in Australia turned her into a long-term international migrant in Europe, with responsibilities for her own home. To the relief of her family support network, she added a parallel paternal network support from her new husband's family in Europe who live near her apartment and are a regular presence in her life.

These women involve themselves in work traditionally preferentially attributed to women. The middle-aged and elderly women, the research genealogy informants, highlight their own judgments of the capacities and incapacities of these migrants, independent of the proximity of their relatedness, to deal with what they expect of daughters, of wives and of mothers - childcare, dedication, sacrifice, and group solidarity. They emphasize the sacrifices that the grandparental, now relatively immobile, generation makes, taking on authoritative motherly duties to assure the success of the migrants' forays out to the world. The comments about the migrants' difficult integration with people and cultures of other nations underline, symbolically, the perceived inhospitality of distant destinations, simultaneously contributed to an image of "courageous undertakings" and of the importance of the preservation of traditions associated with Brazilian family origins, very loosely associated with the traditional emblems of Brazilianness that are cited in studies that emphasize more the retention of national cultures than the building and rebuilding of kin and related support networks. In short, kinship and relatedness are more important features for them than national cultures or the prohibitions stemming from national legislations concerning rights and obligations of citizens across the world. This legality or illegality is not ignored, but in talking about international migration from a point of origin like Recife, which does not define a single or limited number of preferential destinations, national identities and ways to circumvent prohibitive impositions and barriers to mobility by other nations do not have a repetitive, shared nature. Instead of becoming part of a common discourse of individually and shared strategies of astute circumventions of barriers raised by 
country A or country B, they become conversation about behavior of kin and other closely-related people. As mentioned earlier, following Hannerz' comments made earlier, relational aspects are treated as having stranger meanings than "global and local" cultures and legislations.

Travel for continuing study or specializing in some specific knowledge tended to not be considered "migration", especially when the study was done over a defined period of time which viewed return as one of the principal aims. When her aunt says that Ruth went to Germany "to study the German language," she is quick to complement the information with narratives about her courting, marriage and troublesome conjugal relations as part of a relatively definitive move to that country. Narratives about migrants' success in work, employment and income generation are surprisingly sparse. The case of Maria who went to Spain to work is the only one of the four in which the importance of autonomous earning is emphasized, and this occurs as a kind of indirect praising of Maria's recognition of her responsibility as a separated mother concerned with her children's welfare. The concern that her marriage with a Spaniard, and the resistance of her children to leave their Brazilian grandmother's home, might result in diminished support for her children in the future is a very present worry for the grandmother. But, in general, the very limited value put on monetary and work success was very evident among the migration narratives heard. Lea's sacrifice in which she followed her husband to bring up her children only finding occasional income sources, Ruth's strategy of finding a husband who preferred that she not work, and Samantha's short period of employment in a Swiss factory affected by the economic crisis, all point to the fact that the older generation genealogy informants deal with work problems and success as of understandably less importance than the preservation and construction of their relational networks and the constant internet and telephone conversations that are one of the principal means of this preservation. For the few male migrants in the Recife genealogies, there was much clearer emphasis on the importance of income and work success abroad.

There are no references to leaving the country because of personal victimization of violence, yet all the narrators point to the structural insecurity generated by the lack of opportunities for work in Brazil, even those who did not migrate overtly in function of a search for employment. Physical security or recreational opportunities do not figure in these narratives. An interesting 
inversion in this pattern is in Samantha's case, where the precariousness of her study, her trajectory as a dependent integrant in residential circulation between $\mathrm{kin}^{8}$ and the low expectations about her employment possibilities led her aunt to complain that Samantha is very careful to avoid the subject of work and income in their skype and internet conversations, preferring to emphasize her enjoyable leisure trips to Portugal, Greece and other tourist destinations. Her aunt sees this is a very astute way in which Samantha can avoid having to talk about her and her husband's precarious limited income and skills.

\section{Flexibilty, resistance and astuteness: constructing networks, rights and obligation across boundaries}

Crossing a national boundary, one must be aware of different migration policies and legislation. As observed elsewhere (Scott, 2007), in the European Community, even in a period of intense closing of boundaries with a diversity of obstacles to mobility, the clearest way to avoid these obstacles is to fit into categories which evoke the logic of "family reunification", which has a double meaning: the easing of admission of immediate relatives to form their families in the place of destination, and the easing of admission of migrants who can demonstrate at most a two generational link to citizenship in some European community country (most actively promoted in Italy, Spain and Portugal). This easing of legal impediments to boundary crossing is understood as a humanitarian act which must be respected in spite of extant political and economic national policies. Keeping kin networks in operation is an astute act of resistance which permits that close relatives can aid in overcoming contrary migratory legislation.

When the informants narrated the cases included in their genealogies, as in the cases of Lea and Maria, a content of elder generation disciplinary approval or disapproval takes on more importance than the factual and prejudiced images of arrogance and cultural differences of foreigners that are openly questioned as undesireable. Ruth's family is taken aback by her German husand's family resistance to admit her as a co-resident because she had no work, but her aunt adds her expectations that this may result in her

8 With notable differences, this pattern brings to mind the circulation of dependent elderly described by Clarice Peixoto and Mattos (2007). 
finally searching for some kind of work to sustain herself (if her husband doesn't take on all the responsibility, as he seems to prefer). This results in a cascade of anti-German sentiment, characterizing them as ill-mannered, gross, cold and dry, and leads her to evoke stories about the nation's lamentable performance in the Second World War. More than a concern about German culture, Ruth's aunt is worried about the attitudes of her nieces, who she judges as becoming "stuck up" (de nariz arrebitada") only because they are migrants living in Europe and Germany.

Repeatedly, when Lea's sister talks about the problems her nieces (Lea's daugthters) faced in school because the Portuguese displayed prejudice against Brazilians, she quickly adds that the open and gregarious nature of her Brazilian nieces made it easier for them to make friends and this served to broach some of the stigma that was inherent in other contexts in that country. This is often shortly followed by an apology that Lea's sister understands why their co-resident grandmother in Portugal worked so hard to teach tastes for food, hygiene, and the Portuguese rough manners in daily interaction as a way of assuring the children would get on well in the new country. This spills over into general comments about it being good that her nieces can learn what Europe has to offer. The most painful part of this was Lea's loss of autonomy as a result of her residential dependency, and, in that respect national differences flourished in conversation about conflicts that concern negotiations about family hierarchies in any situation.

When Maria decided to go to Spain her collaborative mother-in-law classified Maria's decision as a crazy move of a mother who was very liberal and who had shown more than once that she did not have a firm hand (tem pouco pulso) not only on disciplinary and caring issues, but because of her willingness to accept terrible working conditions and a loss of public face because of her profession, thing that would never have occurred to her in Brazil, even when she was facing repeated unemployment. At this point, the attempt to convince her daughter to move to Spain provokes her grandmother to use a narrative display of cultural prejudice as experienced by her granddaughter: about bad Spanish food (according to the little girl nothing was tasty, except for the shrimp, and she got tired of eating only shrimp!) and strict rules put down by a demanding stepfather. In fact, this justifies the mother-in-law's preference to keep caring for her granddaugther, investing her very valued Brazilian education, in a re-editon of what was identified 
earlier in this text as part of the grandmother syndrome. The grandmother leaves a crack open in the door, as she praises Maria's efforts as a very conscious mother because she sends money back to support her children, and that might be a way of her convincing her other children to reunite with her in Europe at some future time.

The historically network-dependent Samantha goes through a change in Switzerland, where she became a self-supporting autonomous person with a new daily routine, even if part of this self-sufficiency might be better seen as a transfer of responsibility to the patrilateral relatives, who get together with her Brazilian network to allow regular annual visits on special dates to her Brazilian families, circulating from one house to another.

Brazilianness recreated abroad is intensified through its contrast with the countries of destination. The continuity of kinship networks rests heavily on how astute elder generations are in conferring meanings which allow international experience to be understood as an occasion in which these generations continue to reaffirm their important role in the material, symbolic and relational preservation of relational networks. At the same time they call attention to how different cultures with their particularities of interaction can still contribute to the self-sufficiency of migrants, there are serious limits to this gaining of autonomy. Showing success in their endeavor to better their life, migrants may understate their submission to other networks and other rules that may have power to subordinate migrants hierarchically while abroad. Most try to turn this experience into a chance to contribute to more solid network relations, even in spite of the strains that may appear because of displays of arrogance or overstatements of success by the migrants themselves or of their new relations and the constraints that they put on this display.

Either having family in the place of destination or forming a family to get there, or after getting there, can be a very effective means of defying international legal barriers to mobility. Kinship, legislation and culture are all tools for strong disciplinary agency which creates and recreates hierarchies in relatedness networks. This set of hierarchies contributes to the articulation of strategies which contribute to flows and counterflows of information, material and relations which preserve a plurality of networks maintained by the search for solidarity at a distance and the re-elaboration of cultural meanings.

Internationally mobile youth and young adults provoke redefinitions and reaffirmations of generational hierarchies, but they do not reduce the agency 
of elder generations schooled in network formation where they have both authority and affection to their favor if they operate wisely. Distance may contribute to autonomy and responsibility, but it need not corrode relational networks that can become tools for increasing access to rights to mobility and support in difficult times, multiplying the number of houses of reference and parts of networks which may come into play over their life courses. Emotionally and/or financially there is a partial reconfiguration of power relations between generations. Being spatially distant from a family of origin does not mean being excluded from the preservation and recreation of interrelated networks. It permits a questioning of traditions which change their meanings as they are seen from different points of the network, and these networks have a strategic agency in overcoming, or at least questioning, national legal constraints to mobility.

\section{Final Considerations}

Four cases cannot lead to any conclusions, but certainly their close examination suggests some possibilities for interpretation that have been presented in these pages. Rather than return to each one, it may be more instructive to frame two general questions which are both raised and reinforced by the effort to understand the experiences of Lea, Maria, Ruth and Samantha, who all went to different countries in Europe, as they were told by elder generation women talking about international migrations as part of their genealogies.

First, women's migration flows from Latin America to Europe occur in a context in which European women are increasing their participation in the labor market and preserving reduced fecundity rates. These women want other women to do caretaking and cleaning jobs for them so that they can earn more income and more prestige in other jobs. Men from these countries search companionship and domestic service as well, and chose to marry many of these migrants from other countries for those reasons. The increase in women's international migration, even if it may furnish hitherto unequaled opportunities for greater autonomy and independent incomes for the women migrants, can be seen as a double gender relation subordination aggravated by class and ethno-national implications on transnational hierarchies. Closely examined, the four cases of international migration reinforce the intensity of patrilateral network control over children and over the women themselves. Obviously female agency is an important component of 
migration, and the internal gender relations of intercultural marriages with women from less developed countries deserve special attention to understand to what degree and under what limitations it is possible to understand migration as a way to women's autonomy and prestige.

Second, understanding that intergenerational solidarity and tension have deep historical roots and that the internationalization of mobility confers value to destinations, changes and continuities in intergenerational relations need to be carefully examined to understand the structuring of networks that rely on hierarchical differences that permeate kin and relatedness networks formed at a distance. The formation of international networks of kin solidarity becomes a strategy of resistance and of astuteness that can weaken national barriers to mobility by appeal to the idea of family as a symbolically-loaded term (more than generation itself). Most of those that examine transnational families pay attention to long-term flows that have established significant intercultural communities at both of their endpoints (which can also be seen as starting points). There is a more intense shared meaning and interpretation of cultural differences when flows are between such points. When migration is more dispersed, as in Recife, the interpretations of different national cultural contents are more individualized, strategies are more plural and the underlying importance of kin networks and generational respect become proportionately more important measures to decide strategies of mobility and to attribute meanings to them. Obligations, rights and loyalties forged in mobility, then, are articulations between the intimacy and hierarchies of generations, families and kin, on the one side, and contextual sociopolitical structures on the other.

\section{Bibliography}

ANTHIAS, Floya. 2000. "Metaphors of home: gendering recent migrations to Southern Europe”. In: Floya Anthias; Gabriella Lizardis (orgs.), Gender and migration in Southern Europe:women on the move. Oxford: Berg. pp. 15-49.

ARANGO, Joaquim. 2007. "Las migraciones internacionales en un mundo globalizado". Vanguardia dossier: inmigrantes el continente móvil, 22: pp. 6-15. ASSIS, Gláucia de Oliveira. 2003. “'De Criciúma para o mundo' - os novos fluxos da população brasileira: gênero e rearranjos familiares”. In: Ana Cristina Braga Martes; Soraya Fleischer (orgs.), Fronteiras cruzadas: etnicidade, gênero e 
redes sociais. São Paulo: Paz e Terra. pp.199-230.

BARROS, Myriam Lins de. 1987. Autoridade e afeto: avós, filhos e netos na familia brasileira. Rio de Janeiro: Zahar.

BARNARD, Alan; GOOD, Anthony. 1984. Research practices in the study of kinship. London: Academic Press.

CACHÓN, Lorenzo. 2006. "Diez notas sobre la inmigración en España”. Vanguardia: Dossier imigrantes: el continente móvil, 22: 68-75.

CADERNOS PAGU. 2005. "Dossiê Gênero no mercado de sexo", 25(3) (org. Adriana Piscitelli), Campinas. http://www.scielo.br/scielo.php?pid=So104$83332005000200001 \&$ script=sci_arttext

CADERNOS PAGU. 2008. "Dossiê Transito", 31(1) (org. Adriana Piscitelli), Campinas.

CARSTEN, Janet. 2004. After Kinship. Cambridge: Cambridge University. (http://books.google.com.br/books?id=5CU8MLEqnEYC\&printsec=fr ontcover\&dq=JANET+CARSTEN\&source=bl\&ots=ZXqDVVe1K5\&sig=ZIsAf1Ibk5UXngSOHNohinYCPs\&hl=pt-BR\&ei=ZW6FTcznF8yEoQHfv$8 \mathrm{DKCA} \& \mathrm{sa}=\mathrm{X} \&$ oi=book_result $\& \mathrm{ct}=$ result $\&$ resnum $=5 \& v e d=0 C D 4 \mathrm{Q} 6 \mathrm{AEwB}$ $\mathrm{A} \# \mathrm{~V}=$ onepage $\& \mathrm{q} \& \mathrm{f}=$ false

CASTRO, Mary Garcia (coord.). 2001. Migrações internacionais: contribuições para políticas. Brasília: CNPD.

CLIFFORD, James. 2000. “Culturas viajantes”. In: A. A. Arantes (org.), O espaço da diferença. Campinas, SP: Papirus. pp. 51-79.

DALSGAARD, Anne Line; FRANCH, Monica; SCOTT, Parry. 2008. "Dominant ideas, uncertain lives: the meaning of youth in Recife". In: K. Hansen et al. (orgs.), Youth and the city in the global south. Bloomington and Indianapolis: Indiana University Press. pp. 49-73.

DEBERT, Guita Grin. 1999. A reinvenção da velhice. São Paulo: Edusp/ Fapesp. DE TONA, Carla. 2011. "Mothering contradictory diasporas: negotiation of traditional motherhood roles among italian migrant women in Ireland". In: Loretta Baldassar; Donna Gabaccia (eds.), Intimacy and Italian migration. gender and domestic lives in a mobile world. Fordham: Fordham University Press. pp. 101-111.

DURHAM, Eunice R. 1973. A caminho da cidade: a vida rural e a migração para São Paulo. São Paulo: Ed. Perspectiva.

FELDMAN-BIANCO, Bela. (org.). 2010. Nações e diásporas: estudos comparativos entre Brasil e Portugal. Campinas: Editora da Unicamp. 
FERREIRA, A. P; VAINER, Carlos; POVOA NETO, Hélion; SANTOS, Miriam (orgs.). 2010. A experiência migrante: entre deslocamentos e reconstruções. Rio de Janeiro: Garamond.

FONSECA, Claudia. 2007. "Apresentação - De familia, reprodução e parentesco: algumas considerações”. Cadernos Pagu. "Dossiê Repensando Relações Familiares". 29: 9-35.

FRANCH, Monica. 2008. Tempos, contratempos e passatempos: um estudo sobre práticas e sentidos do tempo entre jovens de grupos populares do Grande Recife. Tese de doutoramento, IFCS/UFRJ, Rio de Janeiro.

FUNDAÇAO ALEXANDRE DE GUSMAO. 2008a. Brasileiros no mundo: I Conferencia sobre as comunidades brasileiras no exterior. Textos acadêmicos. vol I. Brasília: Fundação Alexandre de Gusmão.

FUNDAÇAO ALEXANDRE DE GUSMAO. 2008b. Brasileiros no mundo: I Conferencia sobre as comunidades brasileiras no exterior. Textos acadêmicos. vol 2. Brasília: Fundação Alexandre de Gusmão.

FUSCO, Wilson. 2001. "Redes sociais nas migrações entre Governador Valadares e os Estados Unidos”. In: Mary Garcia Castro (coord.), Migrações internacionais: contribuições para políticas. Brasília: CNPD. pp. 427-445.

HANNERZ, Ulf. 1999. "Os limites de nosso auto-retrato. Antropologia urbana e globalização”, Mana. Estudos de Antropologia Social, 5(1): 149-155.

HANNERZ, Ulf. 1979. "Fluxos, fronteiras, hibridos: Palavras-chave da antropologia transnacional”, Mana. Estudos de Antropologia Social, 3(1): 7-39.

MAGNANI, José Guilherme Cantor. 1998. Festa no pedaço: lazer e cultura popular na cidade, $2^{a}$ ediçao. São Paulo: Hucitec.

MARTES, Ana Cristina Braga; FLEISCHER, Soraya (org.) 2003. Fronteiras cruzadas: etnicidade, gênero e redes sociais. São Paulo: Paz e Terra.

MÜLLER, Elaine. 2008. A transição é a vida inteira: uma etnografia sobre os sentidos e a assunção da adultez. Tese de Doutoramento, PPGA/UFPE, Recife. PEIXOTO, Clarice Ehlers; MATTOS, G. 2007. "De uma morada à outra: processos de re-coabitação entre as gerações”. Cadernos Pagu, 29: 171-191.

PINA CABRAL, João de. 2003. O homem na familia: cinco ensaois de antropologia social. Lisboa: Imprensa de Ciências Sociais.

PISCITELli, Adriana. 2008. "Entre 'máfias' e a 'ajuda': a construção de conhecimento sobre tráfico de pessoas”. Cadernos Pagu, Dossiê Trânsitos, 31: $29-63$.

POJMANN, Wendy. 2011. "Mothering across boundaries: immigrant domestic 
workers and gender roles in Italy". In: Loretta Baldasser e Donna Gabaccia (eds.) Intimacy and Italian migration. Gender and domestic lives in a mobile world. Fordham: Fordham University Press. pp. 127-139.

PORTES, Alejandro; DEWIND, Josh (eds.). 2007. Rethinking migration. New theoretical and empirical perspectives. New York/Oxford: Berghahn Books. ROCA GIRONA, Jordi. 2007. "Migrantes por amor. La búsqueda y formación de la pareja transnacional". AIBR. Revista da Antropologia Iberoamericana, 2(3): 430-458.

SCHWEIZER, D. Sc., Luciano. 2008. "Remessas de brasileiros no exterior. Brasileiros nos Estados Unidos”. In: Fundação Alexandre de Gusmão. Brasileiros no mundo: I Conferencia sobre as comunidades brasileiras no exterior. textos acadêmicos. Vol I. Brasília: Fundação Alexandre Gusmão. pp. 181-200. SCOTT, Parry. 2004. "Familia, gênero e poder no Brasil no Século XX," BIB- Boletim Informativo e Bibliográfico das Ciências Sociais, 58(2): 29-78. Reproduced in SCOTT, Parry. 2011. Familias brasileiras: solidariedades, poderes e desigualdades. Recife: EDUFPE.

SCOTT, Parry. 2011. "Fluxos migratórios femininos, desigualdades, autonimazação e violência". In: Silvia Maria Favero Arend; Carmen Silvia de Moraes Rial; Joana Maria Pedro (orgs.), Diásporas, mobilidades e migrações. Ilha de Santa Catarina: Mulheres. pp. 47-66.

SCOTT, Parry. 2007. "A familia espanhola e a receptividade a migrantes brasileiros". Anais do V Encontro Nacional de Migrações, Campinas, ABEPNEPO, CD Rom.

SCOTT, R. Parry; FRANCH, Monica. 2005 [2001]. "Jovens, moradia e reprodução social: processos domésticos e espaciais na aquisição de habilidades e conhecimentos". Estudos de Sociologia: Revista do Programa de Pós-Graduação em Sociologia ${ }_{2}$ 7(1-2): 95-125.

TAVARES, Mauricio Antunes. 2009. Caminhos cruzados, trajetórias entrelaçadas: jovens entre o campo e a cidade no sertão de Pernambuco. Tese de doutoramento, PPGS-UFPE, Recife.

THERBORN, Goran. 2006. Sexo e poder: as familias no mundo 1900-2000. São Paulo: Contexto. 


\section{About the author}

The author is full professor of anthropology in the Department of Anthropology and Museum Studies at the Center of Philosophy and Human Sciences of the Federal University of Pernambuco. He obtained his doctorate at the University of Texas at Austin in 1981 and is presently Coordinator of the Research Group on Family, Gender and Secuality (FAGES).

Address: Av. Manoel Borba, 1000, apto 2003, Boa Vista, Recife, PE, 50070-000. e-mail: Scott@hotlink.com.br

Received 16/11/2011, approved 7/12/2011 